\title{
Cytotoxic, Genotoxic, and Apoptotic Effects of Nickel Oxide Nanoparticles in Intestinal Epithelial Cells
}

\section{Nikel Oksit Nanopartiküllerinin Bağırsak Epitel Hücreleri Üzerine Sitotoksik, Genotoksik ve Apoptotik Etkileri}

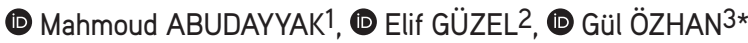 \\ 1Karadeniz Technical University Faculty of Pharmacy, Department of Toxicology, Trabzon, Turkey \\ 2İstanbul University-Cerrahpaşa, Cerrahpaşa Faculty of Medicine, Department of Histology and Embryology, Istanbul, Turkey \\ 3istanbul University Faculty of Pharmacy, Department of Pharmaceutical Toxicology, Istanbul, Turkey
}

\begin{abstract}
Objectives: The superior properties of nickel oxide-nanoparticles (NiO-NPs) have led to their wide use in various fields. However, there is little comprehensive knowledge about their toxicity, especially after oral exposure. The toxic effect of NiO-NPs of mean size $15.0 \mathrm{~nm}$ was investigated in Caco-2 (human intestinal epithelial) cells as no study has been performed on their intestinal toxicity.

Materials and Methods: Following identification of their particle size distribution and cellular uptake potential, the risk of exposure to NiO-NPs was evaluated by cellular morphologic changes, cyto- and genotoxic potentials, oxidative damage, and apoptotic induction.

Results: NiO-NPs induced a $50 \%$ reduction in cell viability at $351.6 \mu \mathrm{g} / \mathrm{mL}$ and caused DNA damage and oxidative damage at $30-150 \mu \mathrm{g} / \mathrm{mL}$. It appears that apoptosis might be a main cell death mechanism in NiO-NP-exposed intestinal cells.

Conclusion: NiO-NPs might be hazardous to the gastrointestinal system. The results should raise concerns about using NiO-NPs in food-contact appliances and about NiO-NP-containing wastes. Further in vivo and in vitro research should be conducted to explain the specific toxicity mechanism of these particles and reduce their risk to humans.
\end{abstract}

Key words: Nickel oxide nanoparticles, intestinal cells, genotoxicity, oxidative stress, apoptosis

öz

Amaç: Nikel oksit-nanopartikülleri (NiO-NP), üstün özellikleri nedeniyle farklı alanlarda geniş kullanıma sahiptir. Ancak, özellikle oral maruziyete NiO-NP'nin toksisiteleri hakkındaki yeterli bilgi bulunmamaktadır. NiO-NP'nin intestinal sistem üzerine toksik etkisi ile ilgili herhangi bir çalıșma bulunmadığından, bu çalıșmada NiO-NP'nin (ortalama boyut 15,0 nm) Caco-2 (insan intestinal epiteli) hücreleri üzerine toksisitesi araştırılmıştır.

Gereç ve Yöntemler: Partikül boyutu dağılımı ve hücresel alım potansiyelleri belirlendikten sonar, NiO-NP'ne maruziyerin riski hücresel morfolojik değişiklikler, sito- ve genotoksik etkiler, oksidatif hasar ve apoptoz indüksiyonu ile değerlendirilmiștir.

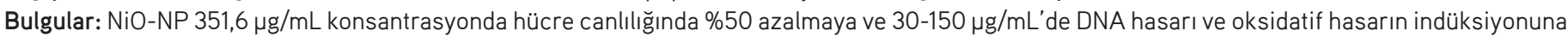
neden olmuştur. NiO-NP'ye maruz bırakılan intestinal hücrelerde ana hücre ölüm mekanizması apoptoz olabilir.

Sonuç: NiO-NP gastrointestinal sisteme tehlikeli olabilir. Elde edilen sonuçlar, gıdayla temas eden cihazların yapımında NiO-NP'nin kullanımı ve $\mathrm{NiO}-\mathrm{NP}$ içeren atıklar nedeniyle endișeler olabileceğini göstermektedir. NiO-NP'in spesifik toksisite mekanizmalarını aydınlatmak ve insan sağlı̆̆ı üzerine risklerini azaltmak için daha ileri in vivo ve in vitro araştırmaların yapılması gerekmektedir.

Anahtar kelimeler: Nikel oksit nanopartikülleri, intestinal hücreler, genotoksisite, oksidatif stres, apoptoz

*Correspondence: E-mail: gulozhan@istanbul.edu.tr, Phone: +90 2124400255 ORCID-ID: orcid.org/0000-0002-6926-5723

Received: 11.03.2019, Accepted: 20.06.2019

๑Turk J Pharm Sci, Published by Galenos Publishing House. 


\section{INTRODUCTION}

Nickel oxide-nanoparticles (NiO-NPs) are widely used as catalysts, pigments, and sensors in different medical and industrial applications because of their physicochemical features.1.2 $\mathrm{NiO}$ and other $\mathrm{Ni}$ compounds are regarded as carcinogenic to humans (Group 1). ${ }^{3}$ Additionally, NiO-NPs are thought to be more toxic than fine particles are because they have high solubility and release higher amounts of ions in medium. ${ }^{4}$ Research has mainly focused on their pulmonary toxicity and reported that the particles induced oxidative stress and inflammatory responses in the airway system. ${ }^{5-10} \mathrm{NiO}-\mathrm{NPs}$ were detected in intestinal tissue after pulmonary exposure. ${ }^{11}$ Although it is well known that NiO-NPs could be absorbed through the intestinal tract, there are very few data about the intestinal toxicity of NiO-NPs. NiO-NPs might be harmful to the cells of mucosa.12,13 On the other hand, the unabsorbed portion is still considered a risk for intestinal cells following oral exposure.

Therefore, in the present study, the toxicity of NiO-NPs was assessed using various endpoints in the Caco-2 human intestine cell line, a highly differentiated human cell line and extensively used to study apical uptake and absorption of nutrients and chemicals as an in vitro model for toxicological studies. ${ }^{14,15}$ Several studies have also reported the chemical permeability to Caco-2 cells to be correlated well with that of the intestinal membrane in vivo. ${ }^{16}$

\section{MATERIALS AND METHODS}

NiO-NPs were obtained from Sigma (St. Louis, MO, USA) and recharacterized using transmission electron microscopy (TEM) (JEM-2100 HR, JEOL, USA) and dynamic light scattering (DLS) (ZetaSizer Nano-ZS, Malvern Instruments, Malvern, UK) in distilled water and cell culture medium. ${ }^{17,18}$

Human intestinal epithelial cells (Caco-2, HTB-37) were obtained from the American Type Culture Collection (Gaithersburg, MD, USA). The cells were incubated according to the manufacturer's instructions. Cells at a density of $10^{5}-10^{6}$ cells $/ \mathrm{mL}$ were treated with freshly prepared NiO-NPs for $24 \mathrm{~h}$.

To evaluate the cellular uptake potentials of NiO-NPs, inductively coupled plasma-mass spectrometry [(ICP-MS); Thermo Elemental $X$ series 2, USA] was used, while TEM (Jeol-1011, Tokyo, Japan) with an accelerating voltage of $80 \mathrm{kV}$ and an attached digital camera (Olympus-Veleta TEM Camera, Tokyo, Japan) was used to evaluate both cellular uptake and morphology changes at 50 and $100 \mu \mathrm{g} / \mathrm{mL} .^{17,18}$

The cytotoxic activity of NiO-NPs $(50-500 \mu \mathrm{g} / \mathrm{mL})$ was determined using 3-(4,5-dimethylthiazol-2-yl)-2,5diphenyltetrazolium bromide (MTT) and neutral red uptake (NRU) assays. ${ }^{19,20}$ The optical densities were measured by an enzyme linked immunosorbent assay (ELISA) reader system (Epoch, Germany) at 590 and $540 \mathrm{~nm}$ for MTT and NRU, respectively. The enzyme activity inhibition and the accumulation of NR dye in the cells were regarded as cytotoxicity endpoints. The cytotoxicity was calculated compared to that of negative control cells. The median inhibitory concentration $\left(\mathrm{IC}_{50}\right)$ values were expressed as the concentration of NiO-NPs that induced inhibition of $50 \%$ in enzyme activities in cells.

The genotoxic effects of NiO-NPs were determined at concentrations of $15-120 \mu \mathrm{g} / \mathrm{mL}$ by comet assay. ${ }^{21}$ Hydrogen peroxide $\left(\mathrm{H}_{2} \mathrm{O}_{2}\right)(100 \mu \mathrm{M})$ was the positive control. Caco-2 cells were mixed with premelted low-melting point agarose, layered on slides previously coated with agarose, covered with a cover slip, and allow to solidify at $4^{\circ} \mathrm{C}$. Then a lysis solution was used to lyse the cells on the slides (for $1-12 \mathrm{~h}$ at $4^{\circ} \mathrm{C}$ ). Electrophoresis was performed for $20 \mathrm{~min}$ and the slides were rinsed with neutralization buffer and fixed using $99 \%$ ethanol. To score the DNA breaks, ethidium bromide was used to stain the DNA before the examination using a fluorescent microscope supplied with an automated image analysis system (Olympus BX53, Olympus, Tokyo, Japan). The percentage of DNA in the comet tail (tail intensity \%) was used to express the DNA damage to individual cells.

Glutathione (GSH), malondialdehyde (MDA), 8-hydroxy-2'deoxyguanosine (8-OHdG), and protein carbonyl (PC) ELISA oxidative stress determination kits were obtained from Yehua Biological Technology (Shanghai, China), while the dye reagent for the protein assay was purchased from Bio-Rad (Munich, Germany). The oxidative stress parameters in the cells treated with $50-150 \mu \mathrm{g} / \mathrm{mL}$ NiO-NPs were determined according to the manufacturer's instructions and Abudayyak et al..$^{7}$ The results were calculated and expressed per gram of protein.

The Annexin V-FITC/propidium iodide (PI) apoptosis/necrosis detection kit was from BioLegend (San Diego, CA, USA). NiO-NP concentrations were $400-700 \mu \mathrm{g} / \mathrm{mL}$. Based on the manufacturer's instructions, the trypsinized cells were adjusted to be $1 \times 10^{6}$ cells $/ \mathrm{mL}$. Next, $100 \mu \mathrm{L}$ of cell suspension were mixed with $5 \mu \mathrm{L}$ of Annexin V-FITC and $10 \mu \mathrm{L}$ of PI and the resulting mixture was incubated in the dark for $15 \mathrm{~min}$. A phase-contrast fluorescent microscope (Olympus BX53, Olympus, Tokyo, Japan) was used to count the apoptotic and necrotic cells. The percentages of the cells to the total cell amount were expressed as the results of this parameter. ${ }^{17,18}$

\section{Statistical analysis}

The cytotoxicity tests were performed in triplicate on four different days $(n=12)$. The other tests were done in triplicate on three different days $(n=9)$. The data were expressed as mean \pm standard deviation. The statistical analysis was conducted using One-Way ANOVA Dunnett t-test by SPSS version 23 for Windows (SPSS Inc., Chicago, IL, USA) and p less than 0.05 was selected as the level of significance.

\section{RESULTS AND DISCUSSION}

The results of TEM and DLS evaluations obtained from our previous study indicated that the average sizes of $\mathrm{NiO}-\mathrm{NPs}$ were $15.0 \mathrm{~nm}(4.2-38.1 \mathrm{~nm})$ in water and $21.4 \mathrm{~nm}(7.2-60.5 \mathrm{~nm})$ in the cell culture medium. The increase in the medium group might be due the adsorption of medium proteins in the surface of the particles. ${ }^{17,18}$ 
The results of the cellular uptake by ICP-MS indicate that Caco2 cells took up NiO-NPs after exposure to 50 and $100 \mu \mathrm{g} / \mathrm{mL}$ for $24 \mathrm{~h}$ (Table 1). The agglomeration of NiO-NPs at the high concentration could explain the decreases in their cellular uptake at the high exposure concentration in comparison with the lower exposure concentration.

The NiO-NPs were obtained within the cytoplasmic vacuoles at 50 and $150 \mu \mathrm{g} / \mathrm{mL}$ (NPs shown with red arrows). The particle sizes were larger in the exposed cells at $150 \mu \mathrm{g} / \mathrm{mL}$ compared to those at $50 \mu \mathrm{g} / \mathrm{mL}$. Moreover, the number of particle-containing vacuoles in the exposed cells decreased when the concentration of NiO-NPs was increased. Cytoplasmic organelles appeared normal and nuclear and plasma membranes were intact in the exposed cells, as in the negative control cells. Electrondense bodies were visible in the cytoplasm of some cells in both treatment groups. The most notable change in the cells included the presence of electron-lucent large vacuoles filled with NPs. In a few cells at $50 \mu \mathrm{g} / \mathrm{mL}$, the cytoplasmic vacuoles were so large that they induced disruption of the cytoplasm. In addition, abnormal nuclei with indentations in the membrane and chromatin condensation were seen in some cells in both treatment groups (Figures $1 \mathrm{~A}-1 \mathrm{C}$ ).

In all the cells, lipid droplets were observed to increase with increasing NP concentrations, which could be an indicator or feature of the oxidative stress process. ${ }^{22,23}$ According to TEM pictures and ICP-MS analysis, the NiO-NPs toxicity could be related to the uptake and accumulation of NiO-NPs in the cells.

The results of the cytotoxicity evaluation showed a decrease in cell viability depending on concentration manner. The median $I_{50}$ values were 479.15 and $351.6 \mu \mathrm{g} / \mathrm{mL}$ by NRU and MTT tests, respectively (Figure 2). According to previous studies, NiO-

\begin{tabular}{ll}
\multicolumn{2}{l}{ Table 1. Nickel oxide-nanoparticles taken up by Caco-2 cells } \\
Exposure concentration $\left(\mu \mathrm{g} / \mathrm{mL} / 10^{5}\right.$ cells) & $\mathrm{Ni}$ amount $\left(\mathrm{mg} / 10^{5}\right.$ cells) \\
\hline Negative control & $0.19 \pm 0.05$ \\
\hline 50 & $3.29 \pm 0.38$ \\
\hline 100 & $1.31 \pm 0.22$ \\
\hline
\end{tabular}

The assay was performed four times. The results are presented as mean \pm SD Ni: Nickel, SD: Standard deviation
NPs induced cellular death in different human cell lines such as neuron, liver, lung, airway epithelial, and breast cells and rat kidney epithelial cells., 4,,23-27 Our results could indicate that the Caco-2 cell line was more vulnerable than other previously studied cell lines to NiO-NP-induced cytotoxic effects.

The genotoxicity of NiO-NPs was estimated using the comet assay (Figure 3). NiO-NPs caused DNA damage (1.2-1.5-fold;

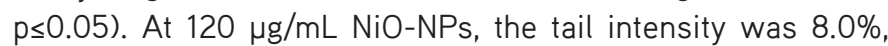
while it was $13.3 \%$ (1.85-fold) in the positive control $(100 \mu \mathrm{M}$ $\mathrm{H}_{2} \mathrm{O}_{2}$ ). Previously, researchers showed that NiO-NPs could induce DNA damage in different cells. ${ }^{28-32}$ Dumala et al. ${ }^{12}$ indicated that NiO-NPs could induce significant DNA damage in the liver, lungs, and kidneys of rats exposed orally to 500 $\mathrm{mg} / \mathrm{kg}$ bw. Moreover, NiO-NPs caused cell cycle alteration as a consequence of genotoxicity via the nuclear translocation of phosho-ATM and phosphor-ATR in human pulmonary epithelial cell lines. ${ }^{12} \mathrm{NiO}-\mathrm{NPs}$ induced the DNA-damage signaling cascade at $20-100 \mu \mathrm{g} / \mathrm{mL}^{18}$ Li et al. ${ }^{33}$ reported DNA damage in pulmonary cells after intratracheal instillation similar to the present results.

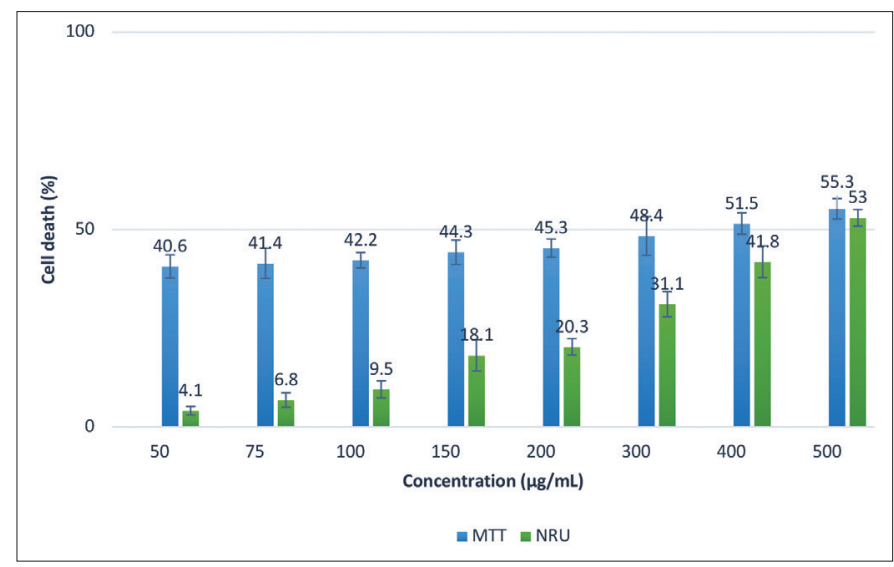

Figure 2. The cytotoxic potential of NiO-NPs

All experiments were done in triplicate and each assay was performed four times. Data are expressed as mean \pm SD. The $I_{50}$ values were $251.6 \mu \mathrm{g} / \mathrm{mL}$ and $479.2 \mu \mathrm{g} / \mathrm{mL}$ in MTT and NRU, respectively

NiO-NPs: Nickel oxide-nanoparticles, SD: Standard deviation, IC ${ }_{50}$ : Inhibitory concentration, MTT: 3-(4,5-dimethylthiazol-2-yl)-2,5-diphenyltetrazolium bromide, NRU: Neutral red uptake
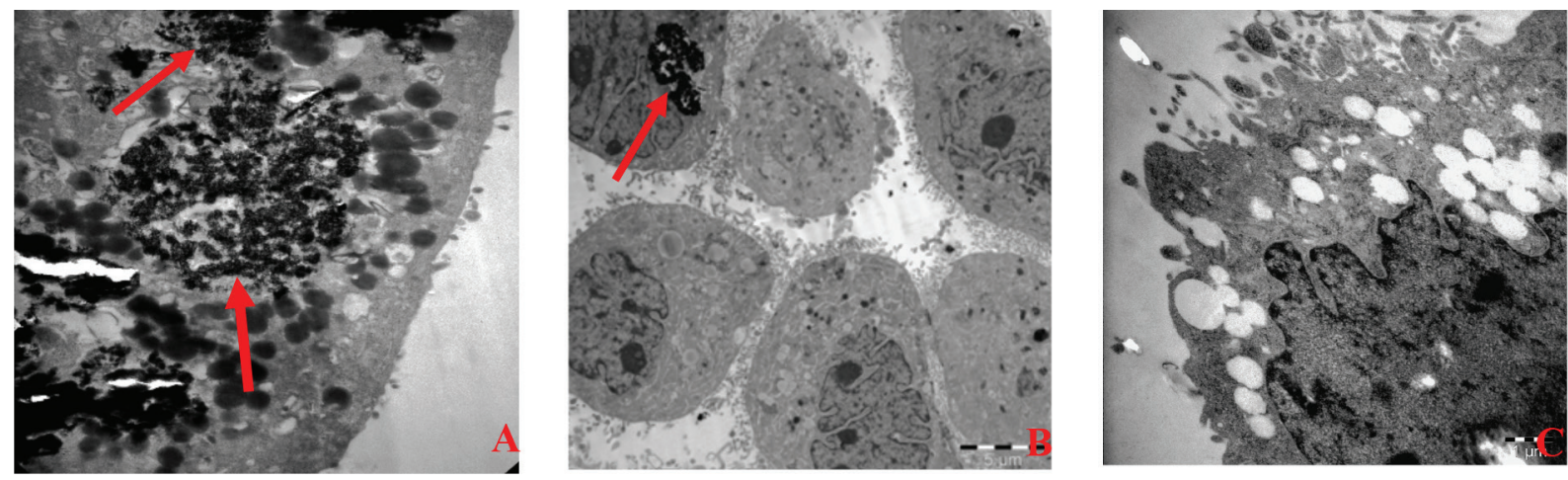

Figure 1. The TEM observations of NiO-NPs uptake by Caco-2 cells

A) Caco-2 cells exposed to NiO-NPs at $50 \mu \mathrm{g} / \mathrm{mL}$, B) Caco-2 cells exposed to NiO-NPs at $100 \mu \mathrm{g} / \mathrm{mL}, \mathrm{C}$ ) Caco-2 unexposed cells (negative control) TEM: Transmission electron microscopy, NiO-NPs: Nickel oxide-nanoparticles 
$\mathrm{NiO}-\mathrm{NP}$-induced oxidative stress was evaluated with the levels of GSH, MDA, 8-OHdG, and PC (Table 2). NiO-NPs induced oxidative stress as a significant increase in the levels of PC ( $\leq 1.5$-fold) and a significant decrease in GSH levels (33.1-37.5\%) were observed. However, 8-OHdG and MDA levels did not change significantly. In general, the oxidative stress potential of $\mathrm{NiO}-\mathrm{NPs}$ in Caco-2 cells was statistically significant $(p \leq 0.05)$.

The previous data showed that NiO-NPs caused damage in the lung and liver and induce pulmonary inflammation via reactive oxygen species (ROS).,8,11,12 In vitro research confirmed with in vivo studies that NiO-NPs induced an increase in ROS and caused oxidative damage in different human cell lines such as liver, lung, airway epithelial, and breast cells. ${ }^{24,26,31,34}$ Previous data confirmed our results; oxidative stress could be the mechanism underlying the cyto- and genotoxicity induced by NiO-NPs.

The Annexin V-FITC/PI assay results demonstrate that NiONPs led to induction of apoptosis (Figure 4 ). The rates of apoptotic cells were $84.6-99.6 \%$ of the dead cells, while the rates of necrotic cells were $0.4-15.4 \%$ of the dead cells (Figure 4). The results indicated that apoptosis might be the main cell death pathway of NiO-NPs. Di Bucchianico et al. ${ }^{24}$ and Saquib et al. $^{34}$ observed an increase in the apoptotic cells rate with

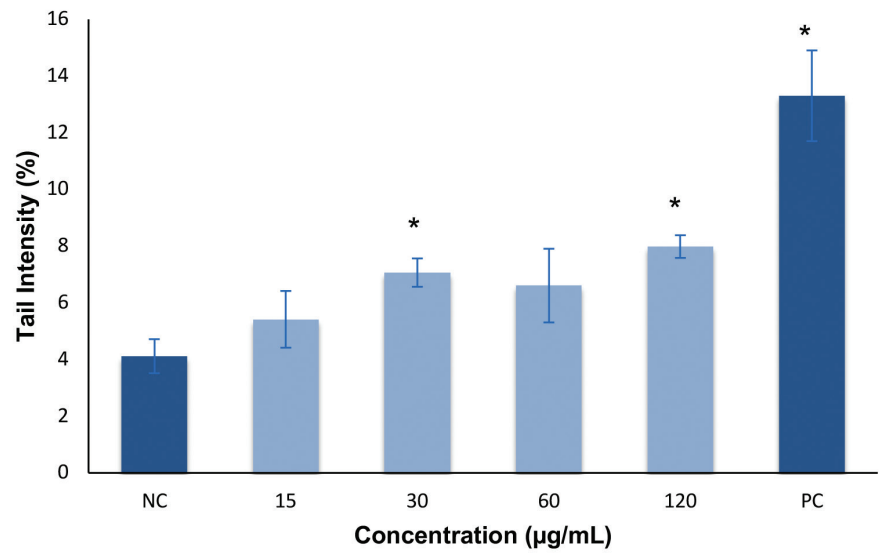

Figure 3. The genotoxic potential of NiO-NPs

All experiments were done in triplicate and each assay was performed three times. The results are presented as mean tail intensity (\%) with \pm SD. ${ }^{*} p \leq 0.05$ was selected as the level of significance by One-Way ANOVA Dunnett t-test NiO-NPs: Nickel oxide-nanoparticles, PC: Protein carbonyl, SD: Standard deviation an increase in NiO-NPs. ${ }^{24,34}$ Similarly, Chang et al. ${ }^{6}$ indicated endoplasmic reticulum stress-related apoptosis in rats exposed to NiO-NPs by intratracheal instillation.

NiO-NPs (25-100 $\mathrm{\mu g} / \mathrm{mL})$ induced apoptosis by functional alterations in mitochondria and lysosomes ${ }^{30}$ similar to our results. Previously, changes in mRNA levels in the genes related to the apoptosis pathway were reported.27,29,34 Duan et al. ${ }^{35}$ studied the role of apoptosis in NiO-NP-induced toxicity in human bronchial epithelial cells (BEAS-2B) by investigating the impacts of NiO-NPs on sirtuin 1, a NAD-dependent deacetylase. NiO-NPs $\left(5-20 \mu \mathrm{g} / \mathrm{cm}^{2}\right)$ caused cytotoxicity by an apoptotic process, and showed a suppression effect on sirtuin 1, which could underlie the NiO-NP-induced apoptosis via tumor protein $\mathrm{p} 53$ and bcl-2-associated $\mathrm{X}$ protein. Similar to previous researchers, we observed that NiO-NPs caused dose-dependent apoptosis. The degree of apoptosis/necrosis corresponded with the severity of cytotoxicity (Figures 2 and 4).

\section{CONCLUSION}

The toxic effects of $\mathrm{NiO}-\mathrm{NPs}(15.0 \mathrm{~nm})$ were evaluated in the Caco- 2 cell line. Our results indicate cellular uptake of NiO-NPs and show cytotoxic potential by disrupting the mitochondrial and lysosomal functions. The median $\mathrm{IC}_{50}$ values were 251.6 $\mu \mathrm{g} / \mathrm{mL}$ and $479.2 \mu \mathrm{g} / \mathrm{mL}$ by MTT and NRU, respectively. Our results also indicate that apoptosis might be the main cell

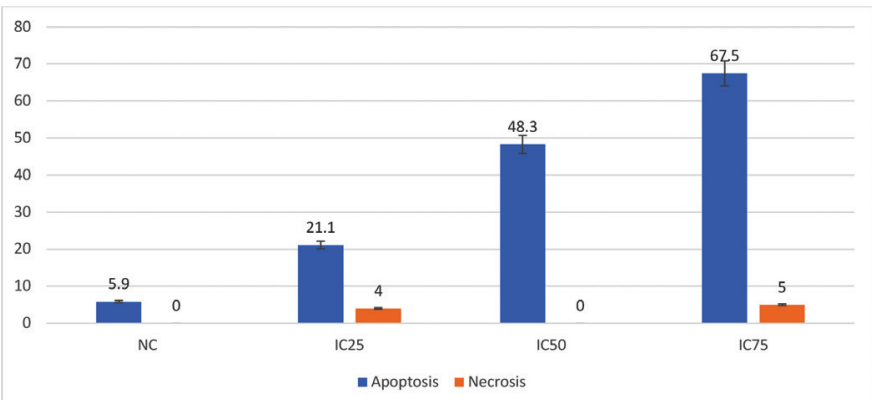

Figure 4. The apoptotic/necrotic potential of NiO-NPs

All experiments were done in triplicate and each assay was performed twice. The results are expressed as the percent of the total cell amount with $\pm \mathrm{SD}, \mathrm{p} \leq 0.05$ was selected as the level of significance by One-Way ANOVA Dunnett t-test. Apoptotic ratio was significant at all exposure samples NiO-NPs: Nickel oxide-nanoparticles, SD: Standard deviation

Table 2. Nickel oxide-nanoparticle induced oxidative damage to Caco-2 cells

\begin{tabular}{lllll} 
Exposure concentration $(\mu \mathrm{g} / \mathrm{mL})$ & $8-\mathrm{OHdG}(\mu \mathrm{g} / \mathrm{g}$ protein) & MDA $(\mu \mathrm{mol} / \mathrm{g}$ protein) & GSH $(\mu \mathrm{mol} / \mathrm{g}$ protein) & PC $(\mu \mathrm{g} / \mathrm{g}$ protein) \\
\hline 0 & $0.917 \pm 0.132$ & $0.350 \pm 0.059$ & $41.142 \pm 2.009$ & $5.160 \pm 0.108$ \\
\hline 50 & $0.964 \pm 0.205$ & $0.375 \pm 0.108$ & $25.744 \pm 3.891^{*}$ & $5.435 \pm 0.814$ \\
\hline 75 & $0.990 \pm 0.242$ & $0.481 \pm 0.090$ & $27.500 \pm 6.082^{*}$ & $6.667 \pm 1.078^{*}$ \\
\hline 100 & $1.111 \pm 0.310$ & $0.408 \pm 0.158$ & $38.092 \pm 3.782$ & $7.115 \pm 0.877^{*}$ \\
\hline 150 & $0.985 \pm 0.164$ & $0.442 \pm 0.098$ & $39.099 \pm 2.82$ & $7.907 \pm 1.007^{\star}$
\end{tabular}

All experiments were done in triplicate and each assay was performed twice. The results were presented as mean \pm SD.

${ }^{*} \mathrm{p} \leq 0.05$ was selected as the level of significance compared to the negative controls by One-Way ANOVA Dunnett t-test, MDA: Malondialdehyde, GSH: Glutathione, PC: Protein carbonyl 
death pathway after treatment with $\mathrm{NiO}-\mathrm{NPs}$ for $24 \mathrm{~h}$. Oxidative stress could be the reason for DNA damage induced by $\mathrm{NiO}$ NPs at $15-120 \mu \mathrm{g} / \mathrm{mL}$ concentrations. These results should raise concern about the safety of products that contain NiO-NPs. Further studies should be conducted to elucidate the probable toxicity in the gastrointestinal tract and clarify the pathways of apoptosis and DNA damage.

\section{ACKNOWLEDGMENTS}

The authors would like to thank to the Research Fund of İstanbul University (Project no: 37785) for supporting this work.

Conflicts of interest: No conflict of interest was declared by the authors. The authors alone are responsible for the content and writing of the paper.

\section{REFERENCES}

1. Capasso L, Camatini M, Gualtieri M. Nickel oxide nanoparticles induce inflammation and genotoxic effect in lung epithelial cells. Toxicol Lett. 2014:226:28-34.

2. Martin A, Sarkar A. Overview on biological implications of metal oxide nanoparticle exposure to human alveolar A549 cell line. Nanotoxicology. 2017;11:713-724.

3. International Agency for Research on Cancer (IARC). Nickel And Nickel Compounds. IARC MONOGRAPHS - 100C. 2018:169-218. https:// monographs.iarc.fr/wp-content/uploads/2018/06/mono100C-10.pdf

4. Horie M, Fukui $H$, Nishio K, Endoh S, Kato H, Fujita K, Miyauchi A, Nakamura A, Shichiri M, Ishida N, Kinugasa S, Morimoto Y, Niki E, Yoshida $\mathrm{Y}$, Iwahashi $\mathrm{H}$. Evaluation of acute oxidative stress induced by $\mathrm{NiO}$ nanoparticles in vivo and in vitro. J Occup Health. 2011;53:64-74.

5. Chang X, Zhao H, Gao J, Chen L, Zhu A, Wang C, Yu S, Ren X, Ge P, Sun $Y$. Pulmonary toxicity of exposure to nano nickel oxide. Micro Nano Lett. 2018;13:733-738.

6. Chang X, Liu F, Tian M, Zhao H, Han A, Sun Y. Nickel oxide nanoparticles induce hepatocyte apoptosis via activating endoplasmic reticulum stress pathways in rats. Environ Toxicol. 2017;32:2492-2499.

7. Horie M, Fukui H, Endoh S, Maru J, Miyauchi A, Shichiri M, Fujita K, Niki E, Hagihara Y, Yoshida Y, Morimoto Y, Iwahashi H. Comparison of acute oxidative stress on rat lung induced by nano and fine-scale, soluble and insoluble metal oxide particles: $\mathrm{NiO}$ and TiO2. Inhal Toxicol. 2012;24:391-400.

8. Marzban A, Seyedalipour B, Mianabadi M, Taravati A. Investigation of the Enzyme activities of Alkaline Phosphatase, Lactate Dehydrogenase, Transaminase and Histopathological Changes of Liver after Exposure to $\mathrm{NiO}$ and NiO Nanoparticles in Rats. JSSU. 2017;25:381-395.

9. Senoh H, Kano H, Suzuki M, Ohnishi M, Kondo H, Takanobu K, Umeda $\mathrm{Y}$, Aiso S, Fukushima S. Comparison of single or multiple intratracheal administration for pulmonary toxic responses of nickel oxide nanoparticles in rats. J Occup Health. 2017;59:112-121.

10. Yu S, Liu F, Wang C, Zhang J, Zhu A, Zou L, Han A, Li J, Chang X, Sun $Y$. Role of oxidative stress in liver toxicity induced by nickel oxide nanoparticles in rats. Mol Med Rep. 2018;17:3133-3139.

11. Shinohara N, Zhang G, Oshima Y, Kobayashi T, Imatanaka N, Nakai M, Sasaki T, Kawaguchi K, Gamo M. Kinetics and dissolution of intratracheally administered nickel oxide nanomaterials in rats. Part Fibre Toxicol. 2017;14:48.

12. Dumala N, Mangalampalli B, Chinde S, Kumari SI, Mahoob M, Rahman MF, Grover P. Genotoxicity study of nickel oxide nanoparticles in female Wistar rats after acute oral exposure. Mutagenesis. 2017;32:417-427.

13. Dumala N, Mangalampalli B, Kalyan Kamal SS, Grover P. Biochemical alterations induced by nickel oxide nanoparticles in female Wistar albino rats after acute oral exposure. Biomarkers. 2018;23:33-43.

14. Käkinen A, Kahru A, Nurmsoo H, Kubo AL, Bondarenko OM. Solubilitydriven toxicity of $\mathrm{CuO}$ nanoparticles to $\mathrm{Caco} 2$ cells and Escherichia coli: Effect of sonication energy and test environment. Toxicol In Vitro. 2016;36:172-179.

15. Martin KR, Failla ML, Smith JC. Differential susceptibility of Caco-2 and HepG2 human cell lines to oxidative stress. J Elisha Mitchell Sci Soc. 1997;113:149-162.

16. Yamashita S, Furubayashi T, Kataoka M, Sakane T, Sezaki H, Tokuda $\mathrm{H}$. Optimized conditions for prediction of intestinal drug permeability using Caco-2 cells. Eur J Pharm Sci. 2000;10:195-204.

17. Abudayyak M, Guzel E, Özhan G. Nickel oxide nanoparticles induce oxidative DNA damage and apoptosis in kidney cell line (NRK-52E). Biol Trace Elem Res. 2017;178:98-104.

18. Abudayyak M, Guzel E, Özhan G. Nickel oxide nanoparticles are highly toxic to SH-SY5Y neuronal cells. Neurochem Int. 2017;108:7-14.

19. Repetto G, del Peso A, Zurita JL. Neutral red uptake assay for the estimation of cell viability/cytotoxicity. Nat Protoc. 2008;3:1125-1131.

20. Van Meerloo J, Kaspers GJL, Cloos J. Cell sensitivity assays: The MTT assay. Methods Mol Biol. 2011;731:237-245.

21. Collins AR. The comet assay for DNA damage and repair principles, applications, and limitations. Mol Biotechnol. 2004;26:249-261.

22. Khatchadourian A, Maysinger D. Lipid droplets: their role in nanoparticleinduced oxidative stress. Mol Pharm. 2009;6:1125-1137.

23. Lee J, Homma T, Kurahashi T, Kang ES, Fujii J. Oxidative stress triggers lipid droplet accumulation in primary cultured hepatocytes by activating fatty acid synthesis. Biochem Biophys Res Commun. 2015;464:229235.

24. Di Bucchianico S, Gliga AR, Åkerlund E, Skoglund S, Wallinder IO, Fadeel B, Karlsson HL. Calcium-dependent cyto- and genotoxicity of nickel metal and nickel oxide nanoparticles in human lung cells. Part Fibre Toxicol. 2018;15:32.

25. Lanone S, Rogerieux F, Geys J, Dupont A, Maillot-Marechal E, Boczkowski J, Lacroix G, Hoet P. Comparative toxicity of 24 manufactured nanoparticles in human alveolar epithelial and macrophage cell lines. Part Fibre Toxicol. 2009;6:14.

26. Mohamed K, Zine K, Fahima K, Abdelfattah E, Sharifudin SM, Duduku K. $\mathrm{NiO}$ nanoparticles induce cytotoxicity mediated through ROS generation and impairing the antioxidant defense in the human lung epithelial cells (A549): Preventive effect of Pistacia lentiscus essential oil. Toxicol Rep. 2018;5:480-488.

27. Siddiqui MA, Ahamed M, Ahmad J, Majeed Khan MA, Musarrat J, Al-Khedhairy AA, Alrokayan SA. Nickel oxide nanoparticles induce cytotoxicity, oxidative stress and apoptosis in cultured human cells that is abrogated by the dietary antioxidant curcumin. Food Chem Toxicol. 2012;50:641-647.

28. Ahamed M. Toxic response of nickel nanoparticles in human lung epithelial A549 cells. Toxicol In Vitro. 2011;25:930-936. 
29. Ahamed M, Ali D, Alhadlaq HA, Akhtar MJ. Nickel oxide nanoparticles exert cytotoxicity via oxidative stress and induce apoptotic response in human liver cells (HepG2). Chemosphere. 2013;93:14-22.

30. A Ahmad J, Alhadlaq HA, Siddiqui MA, Saquib Q, Al-Khedhairy AA, Musarrat J, Ahamed M. Concentration-dependent induction of reactive oxygen species, cell cycle arrest and apoptosis in human liver cells after nickel nanoparticles exposure. Environ Toxicol. 2015;30:137-148.

31. Åkerlund E, Cappellini F, Di Bucchianico S, Islam S, Skoglund S, Derr R, Odnevall Wallinder I, Hendriks G, Karlsson HL. Genotoxic and mutagenic properties of $\mathrm{Ni}$ and $\mathrm{NiO}$ nanoparticles investigated by comet assay, $\gamma-\mathrm{H} 2 \mathrm{AX}$ staining, Hprt mutation assay and ToxTracker reporter cell lines. Environ Mol Mutagen. 2018;59:211-222.

32. De Carli RF, Chaves DDS, Cardozo TR, de Souza AP, Seeber A, Flores WH, Honatel KF, Lehmann M, Dihl RR. Evaluation of the genotoxic properties of nickel oxide nanoparticles in vitro and in vivo. Mutat Res/ Genet Toxicol Environ Mutagen. 2018;836:47-53.

33. Li YS, Ootsuyama Y, Kawasaki Y, Morimoto Y, Higashi T, Kawai K. Oxidative DNA damage in the rat lung induced by intratracheal instillation and inhalation of nanoparticles. J Clin Biochem Nutr. 2018;62:238-241.

34. Saquib Q, Siddiqui MA, Ahmad J, Ansari SM, Faisal M, Wahab Z, Alatar AA, Al-Khedhairy A. Nickel Oxide Nanoparticles Induced Transcriptomic Alterations in HEPG2 Cells. In: Saquib Q, ed. Cellular and Molecular Toxicology of Nanoparticles (1 ${ }^{\text {st }}$ ed). Springer; 2018:163-174.

35. Duan WX, He MD, Mao L, Qian FH, Li YM, Pi HF, Liu C, Chen CH, Lu YH, Cao ZW, Zhang L, Yu ZP, Zhou Z. NiO nanoparticles induce apoptosis through repressing SIRT1 in human bronchial epithelial cells. Toxicol Appl Pharmacol. 2015;286:80-91. 